\title{
Isotherm studies of methylene blue adsorption onto waste tyre pyrolysis powder-based activated carbons
}

\author{
Mohd Shafiq Hakimi Mohd Shaid ${ }^{\text {a, b}}$, Muhammad Abbas Ahmad Zaini ${ }^{\text {a, b, }}{ }^{*}$, Noor Shawal Nasri ${ }^{\text {b, c }}$ \\ a Centre of Lipids Engineering \& Applied Research (CLEAR), Ibnu-Sina Institute for Scientific \& Industrial Research, Universiti Teknologi Malaysia, \\ 81310 UTM Johor Bahru, Johor, Malaysia \\ ${ }^{b}$ Faculty of Chemical \& Energy Engineering, Universiti Teknologi Malaysia, 81310 UTM Johor Bahru, Johor, Malaysia \\ c UTM-MPRC Institute for Oil \& Gas, Universiti Teknologi Malaysia, 81310 UTM Johor Bahru, Johor, Malaysia
}

* Corresponding author: abbas@cheme.utm.my

\section{Article history}

Received 19 November 2017

Accepted 10 December 2017

\begin{abstract}
This study was aimed to investigate the adsorptive ability of activated carbons derived from waste tyre pyrolysis powder by $\mathrm{CO}_{2}$ activation and $\mathrm{ZnCl}_{2}$ activation. The derived activated carbons and char were characterized for yield and specific surface area. Methylene Blue dye was used as a model pollutant to probe the performance of activated carbons. Result shows that the $\mathrm{CO}_{2}$-activated waste tyre pyrolysis powder exhibits a higher surface area of $97.0 \mathrm{~m}^{2} / \mathrm{g}$, hence a greater methylene blue removal capacity of $47.2 \mathrm{mg} / \mathrm{g}$. The methylene blue adsorption data by activated carbons and char obeyed the Langmuir isotherm with $\mathrm{R}^{2}$ of more than 0.99 , describing the monolayer adsorption onto homogeneous surface. Physical activation of waste tyre pyrolysis powder using $\mathrm{CO} 2$ yields activated carbon with a promising performance for dyes removal from water.
\end{abstract}

Keywords: Activated carbon; adsorption; isotherm; methylene blue; waste tyre pyrolysis powder

\section{INTRODUCTION}

Several industries such as paper, printing, dyestuff, textile, carpet, plastic, food and cosmetic used dyes to impart color to the products (Bensalah et al., 2009; Wrobel et al., 2001; Dawood et al., 2014). Every year, over 100,000 of commercially available dyes with more than $7 \times 10^{5}$ ton of dyes are manufactured globally (Lee et al., 2006). Unfortunately, these dyes are eventually end-up as industrial wastes, and consequently are discharged to the water bodies in the form of coloured wastewaters (Lee et al., 1999; Yagub et al., 2014).

According to Rangabhashiyam et al. (2013) a number of treatment strategies including that of physical, chemical and biological methods have been applied to wastewater containing dye contaminants. Out of these, adsorption is a preferred technique because of several advantages, i.e., high efficiency, inexpensive, simplicity of design, ease of operation, ability to remove different colouring materials, works on ambient temperature and pressure, availability of various adsorbents, and small production of by-products and residues, thus an environmentally friendly process (Crini, 2006; Ismail et al., 2013; Reza \& Ahmaruzzaman, 2015). Activated carbon is a commonly used adsorbent for dye adsorption (Jha \& Subedi, 2011; Ahmad et al., 2012). It is also suitable to remove various pollutants in air and water. Now, the search for eco-friendly and low cost precursor of activated carbon has been intensified on wastes and residues from industrial sectors.

Nearly 1.5 billion scrap tyres make their way into the environmental cycle every year (Rowhani \& Rainey, 2016). One scrap tyre is produced per person per year, and this massive disposal of scrap tyres is common in many big cities (Turer, 2012). Two common strategies can be applied to scrap tyres, i.e., disposal and recycle.
Through conventional disposal routes, the waste tyres are incinerated at high temperature or buried in a landfill. However, the disposal routes often result in a number of environmental pollutions and public health effects. The dumping areas, for example would become the breeding sites for flies and mosquitoes, while air pollution from the combustion of tyre increased the potential risk of cancer (Downard et al., 2015; Singh et al., 2015). Hence, the recycle of waste tyre is a long-term solution of this problem.

The end-of life tyre that can no longer be used normally undergone material or energy recovery (Toretta et al., 2015) The scrap tyre is ground into small pieces, and can be used as part of the construction material due to its physical characteristics, i.e., low weight, high drainage capacity, relatively compressible and low thermal conductivity. In energy recovery, low grade fuel can be obtained from waste tyre via pyrolysis. The recycle and recovery processes offer a lot of advantages such as economic return, minimization of hazardous emission and energy integration within the refinery (Hita et al., 2016). However, the pyrolysis of waste tyre inevitably produces secondary waste which is the solid residue, namely scrap tyre pyrolysis powder. Instead of sending the solid residue to a landfill for disposal, it is envisaged that the solid residue can be a promising precursor of activated carbon, which later can be used to treat various pollutants such as dyes and heavy metals. Previous studies reported the chemical activation of waste tyre pyrolysis powder for dyes removal from water (Zaini et al., 2014a,b; Lopez et al., 2013). However, the residue is already rich in carbon content, hence the pre-carbonization may not be necessary. Therefore, the present work was aimed at evaluating the effectiveness of physical activation of waste tyre pyrolysis powder using $\mathrm{CO}_{2} . \mathrm{ZnCl}_{2}$-activated sample and char were also employed for comparison purpose. 
Methylene blue dye was used as model pollutant to probe the adsorption performance, and the adsorption data were analyzed using isotherm models.

\section{EXPERIMENTAL}

\section{Materials}

The waste tyre pyrolysis powder (WTP) of micro-sized particles was obtained from Bukit Batu Brickmill, Kulai, Johor. The is a side product of the low-grade fuel production by pyrolysis of scrap tyre material, and was used as a precursor in the preparation of activated carbons and char. All chemicals are of analytical reagents grade, and were supplied by QReC (Malaysia). $\mathrm{CO}_{2}$ gas was supplied by Mega Mount Gases.

Methylene blue (MB), a cationic dye with empirical formula of $\mathrm{C}_{16} \mathrm{H}_{18} \mathrm{~N}_{3} \mathrm{SCl}$, molecular weight of $319.9 \mathrm{~g} / \mathrm{mol}$ and colour index $(\mathrm{CI})$ of 52015 was used as model pollutant in batch adsorption studies. Fig. 1 shows the chemical structure of methylene blue (Miclescu \& Wiklund, 2010). It is a dark green powder that impart a blue solution when dissolved in water.<smiles>CN(C)c1ccc2nc3ccc(=[N+](C)C)cc-3sc2c1</smiles>

Fig. 1 Methylene blue molecular structure.

\section{Preparation and characterization of activated carbons}

Physical activation using $\mathrm{CO}_{2}$ was carried out with assumption that the pre-carbonization is not necessary because the tyre pyrolysis powder is already rich in carbon content. The desired mass of WTP on a ceramic boat was placed at the centre of tubular furnace. $\mathrm{CO}_{2}$ was allowed to flow inside the tubular furnace for 10 minutes to purge out air (oxygen) to prevent combustion during activation. Then, WTP was heated at $900^{\circ} \mathrm{C}$ in the presence of $\mathrm{CO}_{2}$ for $5 \mathrm{~h}$. The resultant sample was designated as $\mathrm{AC}-\mathrm{CO}_{2}$.

Chemical activation using $\mathrm{ZnCl}_{2}$ was carried out with solid mass ratio of 1:1. The mixture of $\mathrm{ZnCl}_{2}$ solution and WTP was stirred at $80^{\circ} \mathrm{C}$ for $2 \mathrm{~h}$, and then it was oven-dried overnight at $110^{\circ} \mathrm{C}$. After that, the impregnated sample was activated in a muffle furnace at $550^{\circ} \mathrm{C}$ for $2 \mathrm{~h}$. Char was prepared by heating the precursor in air at $550^{\circ} \mathrm{C}$ for $2 \mathrm{~h}$. The resultant samples were designated as $\mathrm{AC}-\mathrm{ZnCl}_{2}$ and AC-Char, respectively.

The WTP was characterized for oil content and ash content. The oil content was determined by dividing the weight of oil with the weight of residual WTP after extraction. The oil was extracted from the surface of WTP by refluxing hexane using Soxhlet. The recovery of oil and solvent was done using a rotary evaporator. The WTP was heated in a furnace at $850^{\circ} \mathrm{C}$ for $2 \mathrm{~h}$. The ash content was calculated by dividing the mass of residue (left-over) with the initial weight of WTP.

Activated carbons and char were characterized for yield and specific surface area. The yield was calculated by dividing the final weight of resultant product with the initial weight of WTP. The surface area of activated carbons and char were obtained using a Pulse Chemisorb 2705 analyzer (Micrometrics, USA). A single-point Brunauer-Emmett-Teller (BET) method was used to calculate the specific surface area.

\section{Batch adsorption studies}

A series of methylene blue (MB) solution of varying concentrations were prepared through dilution from the stock solution. The concentrations are 5, 10, 20,50, 70, 100, 120 and $150 \mathrm{mg} / \mathrm{L}$. Thirty milligrams of sample was added into a flask containing $30 \mathrm{~mL}$ of MB solution of known concentration. The $\mathrm{pH}$ of the MB solution was unaltered. The mixture was allowed to equilibrate for $72 \mathrm{~h}$ at room temperature. The concentration of $\mathrm{MB}$ was analyzed using visible spectrophotometer (Halo Vis-10, Dynamica) at a wavelength of $664 \mathrm{~nm}\left(\mathrm{R}^{2}=0.981\right)$.

The adsorption capacity, $Q_{e}(\mathrm{mg} / \mathrm{g})$ was calculated using the following equations

$$
Q_{e}=\frac{V\left(C_{0}-C_{e}\right)}{M}
$$

where $V(\mathrm{~L})$ is the volume of solution, $M(\mathrm{~g})$ is the mass of activated carbon, $C_{o}(\mathrm{mg} / \mathrm{L})$ is the initial concentration, $C_{e}(\mathrm{mg} / \mathrm{L})$ is the equilibrium concentration.

The adsorption data were analyzed using two well-known empirical isotherm equations, namely Langmuir and Freundlich models. Equations (2) and (3) represent the Langmuir isotherm model and its linear form, respectively,

$$
\begin{aligned}
& \mathrm{Q}_{\mathrm{e}}=\frac{\mathrm{Q}_{\max } \mathrm{K}_{\mathrm{L}} \mathrm{C}_{\mathrm{e}}}{1+\mathrm{K}_{\mathrm{L}} \mathrm{C}_{\mathrm{e}}} \\
& \frac{C_{e}}{Q_{e}}=\frac{C_{e}}{Q_{\max }}+\frac{1}{Q_{\max } K_{L}}
\end{aligned}
$$

where $Q_{\max }(\mathrm{mg} / \mathrm{g})$ is the maximum adsorption capacity and $K_{L}$ $(\mathrm{L} / \mathrm{mg})$ is the Langmuir constant related to the affinity of the binding sites and energy of adsorption. The Langmuir isotherm is based on the assumption that the adsorption is a monolayer coverage on the homogeneous surface of adsorbent (Langmuir, 1918).

Freundlich model and its linear form are expressed in Equations (4) and (5), respectively,

$$
\begin{aligned}
& Q_{e}=K_{F} C_{e}^{1 / n} \\
& \ln Q_{e}=\ln K_{F}+\frac{1}{n} \ln C_{e}
\end{aligned}
$$

where $K_{F}(\mathrm{mg} / \mathrm{g})(\mathrm{L} / \mathrm{mg})^{1 / n}$ is the Freundlich constant related to adsorption capacity and $n$ is the empirical parameter related to adsorption intensity. The Freundlich isotherm describes a multilayertype of adsorption onto the heterogeneous surface structure (Kundu \& Gupta 2006). The isotherm parameters were determined from the slope and intercept of the best fit line with the equilibrium data.

\section{RESULTS AND DISCUSSION}

\section{Characteristics of activated carbons}

The oil content of WTP is $5.02 \%$, while the ash content is $22.4 \%$. The yields of $\mathrm{CO}_{2}$-activated WTP, $\mathrm{ZnCl}_{2}$-activated WTP and char are $48.2 \%, 73.3 \%$ and $91.9 \%$, respectively. The lowest yield was recorded for $\mathrm{AC}-\mathrm{CO}_{2}$. This could be resulted from the excessive burning-off at high temperature of activation $\left(900^{\circ} \mathrm{C}\right)$. Likewise, the yield of $\mathrm{AC}$ $\mathrm{ZnCl}_{2}$ is lower than that of AC-Char because the former undergone impregnation with dehydrating agent $\left(\mathrm{ZnCl}_{2}\right)$, that may as well increase the liberation of volatiles at the expense of the pore development. However, it is also suggested that the impregnation procedure could result in the blockade of pores, and consequently yields activated carbon with low surface area. The properties of activated carbons and char are summarized in Table 1.

Table 1 Properties of activated carbons.

\begin{tabular}{lllll}
\hline Agent & Temp. $\left({ }^{\circ} \mathrm{C}\right)$ & Yield $(\%)$ & $\mathrm{pH}$ & $\begin{array}{l}\text { Surface area } \\
\left(\mathrm{m}^{2} \mathrm{~g}^{-1}\right)\end{array}$ \\
\hline $\mathrm{CO}_{2}$ & 900 & 48.2 & 6.5 & 97.0 \\
$\mathrm{ZnCl}$ & 550 & 73.3 & 5.9 & 10.3 \\
Air & 550 & 91.9 & 6.3 & 58.0 \\
\hline
\end{tabular}

\section{Effect of initial dye concentration}

Fig. 2 shows the equilibrium removal of methylene blue (MB) onto WTP-derived activated carbons and char. In general, the adsorption capacity rapidly increased when the concentration of MB 
increases. It signifies the affinity of MB towards the adsorption onto activated carbons and char is high. Increasing the concentration increases the driving force of mass transfer from the bulk solution to the adsorbent surface sites, and so increasing the amount of $\mathrm{MB}$ adsorption. At certain point of higher concentration, the capacity gradually slowed down, and the uptake seems to leveled-off. This stage is known as surface saturation or maximum capacity (Chen et al., 2011). From Fig. 2, the maximum capacities of MB were recorded as $17.5 \mathrm{mg} / \mathrm{g}, 32.9 \mathrm{mg} / \mathrm{g}$ and $45.1 \mathrm{mg} / \mathrm{g}$ for $\mathrm{AC}-\mathrm{ZnCl}_{2}$, AC-Char and $\mathrm{AC}-\mathrm{CO}_{2}$, respectively. This is directly proportional to the ascending order of the specific surface area of adsorbents produced in this work. The higher the surface area, the more the interaction probabilities between the surface sites and the MB molecules, hence the greater the removal capacity.

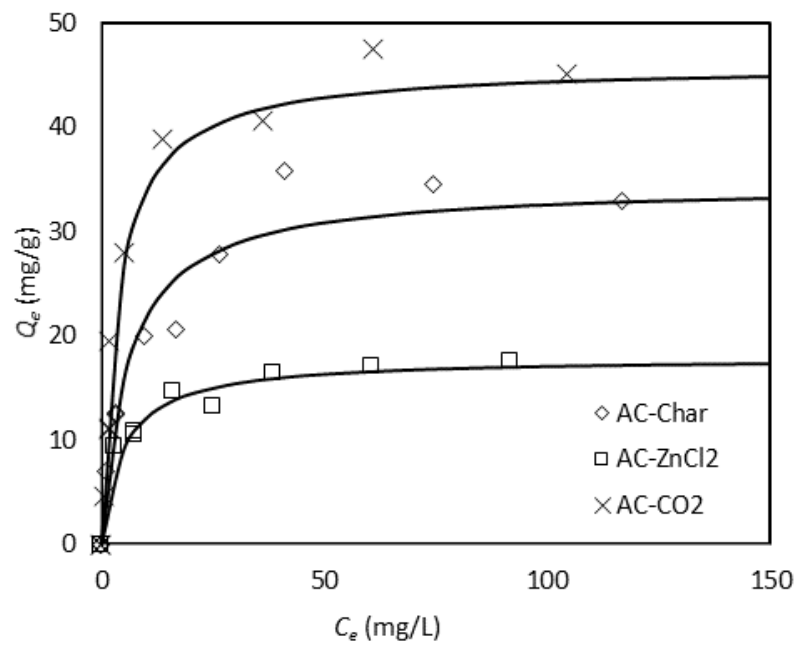

Fig. 2 Methylene blue adsorption onto activated carbons and char (Lines were predicted using Langmuir model).

\section{Equilibrium isotherm studies}

Isotherm study indicates how the adsorbate molecules distribute between the liquid phase and the solid phase when an equilibrium state is achieved in an adsorption process (Guo et al., 2013). Two isotherm models, namely Langmuir and Freundlich equations were used to describe the adsorption data. Fig. 3 shows the Langmuir plots of MB adsorption onto WTP-activated carbons and char. From the linear line of $C_{e} / Q_{e}$ against $C_{e}$, the Langmuir parameters can be determined from the gradient $\left(1 / Q_{\max }\right)$ and intercept $\left(1 / K_{L} Q_{\max }\right)$. The calculated values of $Q_{\max }$ and $K_{L}$ are summarized in Table 2 . The applicability of isotherm equation in explaining the adsorption mechanism is based on the coefficient of determination, $\mathrm{R}^{2}$.

The separation factor, $R_{L}$ of Langmuir isotherm (dimensionless constant, $R_{L}=K_{L}^{-1} C_{o}^{-1}$ ) was used to validate the favourability of the adsorption process. Fig. 4 shows the $R_{L}$ profiles of activated carbons and char. The $R_{L}$ values for MB adsorption are between 0.0025 and 0.520 , i.e., in the range of $0<R_{L}<1$. This shows that the adsorption of $\mathrm{MB}$ onto waste tyre pyrolysis powder based activated carbons and char is a favourable process.

Fig. 5 shows the Freundlich isotherm plots. The Freundlich parameters are summarized in Table 2. The Freundlich constant, $n$ represents the heterogeneous factor which suggests that the adsorption system is either linear when $n=1$, chemical-type $(n<1)$ or physicaltype $(n>1)$. The $n$ values ranging between 2.55 to 5.18 indicates that the process or adsorption system is of physical-type. In addition, the surface heterogeneity can be defined by $1 / n$. The surface is said to be heterogeneous when $1 / n$ approaches zero. In this work, the $1 / n$ values are between 0.193 and 0.392 , suggesting that the surface of adsorbents is highly heterogeneous.

From Table 2, the Langmuir isotherm exhibits higher $\mathrm{R}^{2}$ than the Freundlich isotherm. Thus, the adsorption data of MB onto WTPderived adsorbents obeyed the Langmuir isotherm to linear approximation. The Langmuir model assumes that the adsorption takes place at specific homogeneous sites within the adsorbent, at which once an adsorbate molecule occupies a site, no further adsorption can take place at that site. The acceptable fitting of Langmuir is supported by the close agreement between $Q_{\text {exp }}$ and $Q_{\max }$. AC-CO2 possesses the highest computed monolayer adsorption capacity of $47.5 \mathrm{mg} / \mathrm{g}$.

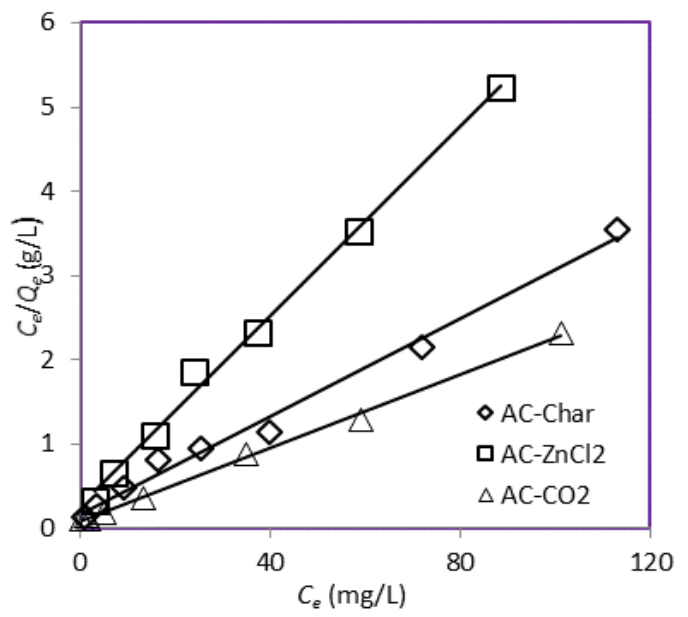

Fig. 3 Langmuir isotherm of MB adsorption.

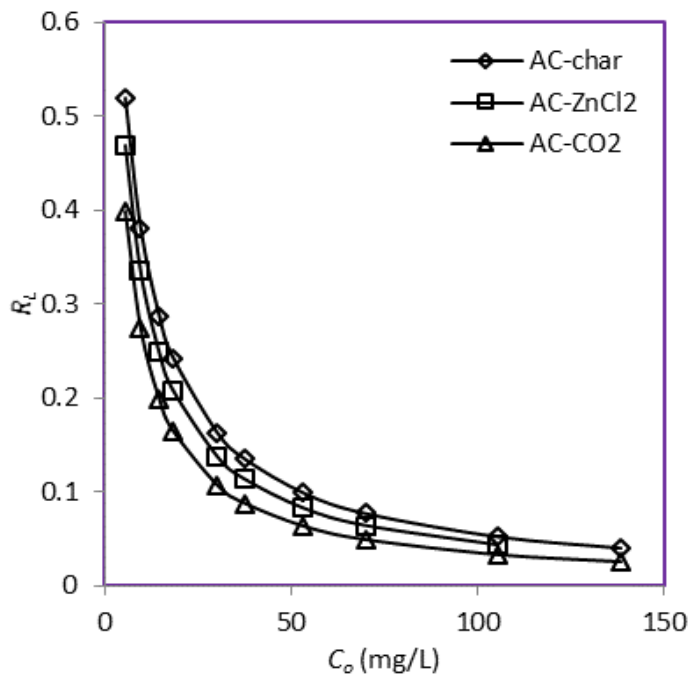

Fig. $4 R_{L}$ profiles.

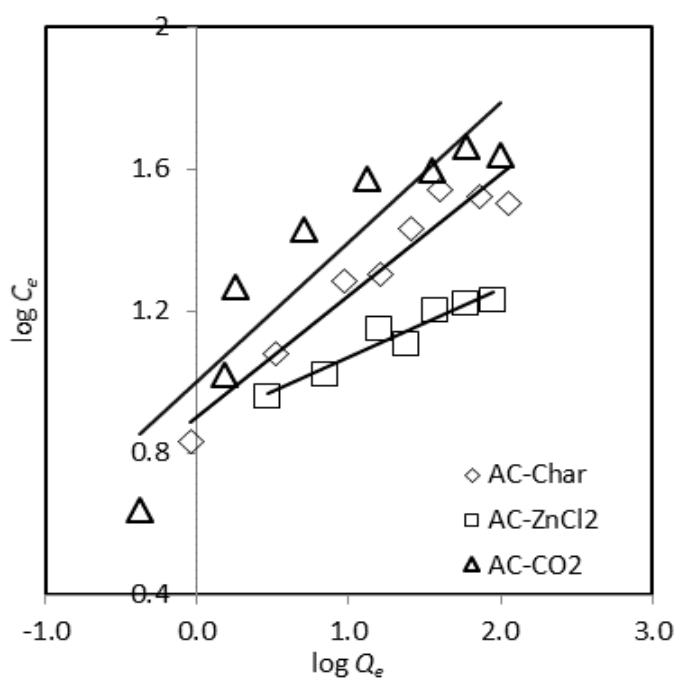

Fig. 5 Freundlich isotherm of MB adsorption. 
Table 2 Parameters of isotherm models

\begin{tabular}{llll}
\hline & $\mathrm{AC}-\mathrm{CO}_{2}$ & $\mathrm{AC}-\mathrm{ZnCl}_{2}$ & $\mathrm{AC}-\mathrm{Char}$ \\
\hline$Q_{\text {exp }}(\mathrm{mg} / \mathrm{g})$ & 47.5 & 17.5 & 34.8 \\
$\quad$ Langmuir Model & & & \\
$Q_{\max }(\mathrm{mg} / \mathrm{g})$ & 45.9 & 17.8 & 34.5 \\
$K_{L}$ & 0.163 & 0.0371 & 2.06 \\
$\mathrm{R}^{2}$ & 0.997 & 0.995 & 0.991 \\
$\quad$ Freundlich model & & & \\
$K_{F}(\mathrm{mg} / \mathrm{g})(\mathrm{L} / \mathrm{mg})^{1 / n}$ & 10.0 & 7.51 & 7.94 \\
$n$ & 2.55 & 5.18 & 2.90 \\
$\mathrm{R}^{2}$ & 0.845 & 0.928 & 0.938 \\
\hline
\end{tabular}

Table 3 summarizes various waste tyre-based activated carbons for water pollutants removal. In general, it shows that the scrap tyre is a promising candidate to produce activated carbons with high specific surface area ranging from $50 \mathrm{~m}^{2} / \mathrm{g}$ to $720 \mathrm{~m}^{2} / \mathrm{g}$ under different activation strategies. Lopez et al. reported that the demineralization of raw material may be needed to reduce unnecessary minerals before activation. The shapes and physical appearances of waste tyre may not necessarily affect the development of surface area. However, previous works on waste tyre pyrolysis residue revealed a poor development of surface area upon chemical activation (Zaini et al., 2014a,b). This could be attributed to the activation strategies and the selection of activating agents. Chemical activation using $\mathrm{ZnCl}_{2}$ and $\mathrm{CaCl}_{2}$ may not be effective for waste tyre powder because of the nature of very fine powder particles, and that the material is already rich in carbon content (Zaini et al., 2014a). It should be noted that the material used in previous works has undergone pyrolysis at elevated temperature to produce low grade fuel, hence the carbonization step to increase the carbon content can be skipped, as demonstrated in this work (Zaini et al., 2014a,b). Definitely, physical activation displays a lower yield (ca. 59\%) of activated carbon compared to chemical activation. However, the BET surface area of the resultant activated carbons by physical activation can be exceptionally high, which is up to 720 $\mathrm{m}^{2} / \mathrm{g}$, while that of chemical activation is around $200 \mathrm{~m}^{2} / \mathrm{g}$ (Table 3 ). This shows that the pretreatment (impregnation) prior to activation does affect the development of surface area. Therefore, by using appropriate operating conditions, it is envisioned that an improved performance of activated carbons could be materialized by physical activation of waste tyre pyrolysis powder for water pollutants removal.

\section{CONCLUSION}

Waste tyre pyrolysis powder was used to synthesize activate carbons by $\mathrm{CO}_{2}$ activation and $\mathrm{ZnCl}_{2}$ activation, and char. The values of specific surface area are $97.0 \mathrm{~m}^{2} / \mathrm{g}, 10.3 \mathrm{~m}^{2} / \mathrm{g}$ and $58 \mathrm{~m}^{2} / \mathrm{g}$, respectively. The adsorption capacity increased with increasing methylene blue (MB) concentration, to a saturation point of maximum uptake. The MB adsorption is surface area-sensitive, and the increasing pattern of maximum capacity is in agreement with the ascending order of the surface area of adsorbents. The isotherm studies display a best fit of Langmuir model with the adsorption data, suggesting a monolayer-type of adsorption onto homogeneous surface sites. Inappropriate activation strategies may impede the development of surface area of waste tyre pyrolysis powder, thus jeopardizing the removal performance. Chemical activation, in particular may not be effective to activate this material. Nevertheless, this limitation could be overcome by appropriate physical activation.

Table 3 Preparation of waste tyre-based activated carbons for water pollutants removal.

\begin{tabular}{|c|c|c|c|c|c|c|c|}
\hline $\begin{array}{l}\text { Physical } \\
\text { appearance } \\
\text { /shape }\end{array}$ & Treatment str & gies & $\begin{array}{l}\text { BET surface } \\
\text { area }\left(\mathrm{m}^{2} / \mathrm{g}\right)\end{array}$ & $\begin{array}{l}\text { Yield } \\
(\%)\end{array}$ & $\begin{array}{l}\text { Carbon and } \\
\text { (ash) } \\
\text { content (\%) }\end{array}$ & $\begin{array}{l}\text { Target pollutant } \\
(\mathrm{mg} / \mathrm{g})\end{array}$ & Reference \\
\hline \multirow{2}{*}{ Fine powder } & $\begin{array}{l}\text { Remove } \\
\text { surface oil: }\end{array}$ & $\begin{array}{l}\text { Activation: } \mathrm{ZnCl}_{2}, 1: 1 \\
550^{\circ} \mathrm{C}, 1.5 \mathrm{~h}\end{array}$ & 288 & 91.2 & $(9.1)$ & $\begin{array}{l}\text { Methylene blue } \\
(154)\end{array}$ & \multirow{2}{*}{$\begin{array}{l}\text { Zaini et al. } \\
(2014 b)\end{array}$} \\
\hline & $\begin{array}{l}\text { Furnace, } \\
250^{\circ} \mathrm{C}, 1.5 \mathrm{~h}\end{array}$ & $\begin{array}{l}\text { Irradiated water } \\
\text { activation (microwave) }\end{array}$ & 113 & 76.0 & $(9.1)$ & $\begin{array}{l}\text { Methylene blue } \\
\text { (83) }\end{array}$ & \\
\hline \multirow{2}{*}{ Fine powder } & $\begin{array}{l}\text { Remove } \\
\text { surface oil: }\end{array}$ & $\begin{array}{l}\text { Irradiated water } \\
\text { activation (microwave) }\end{array}$ & 95.9 & 72.3 & - & $\begin{array}{l}\text { Reactive orange } \\
16(81.3)\end{array}$ & \multirow{2}{*}{$\begin{array}{l}\text { Zaini et al. } \\
\text { (2014a) }\end{array}$} \\
\hline & $\begin{array}{l}\text { Furnace, } \\
250^{\circ} \mathrm{C}, 1.5 \mathrm{~h}\end{array}$ & $\begin{array}{l}\text { Activation: } \mathrm{CaCl}_{2}, 1: 1 \\
550^{\circ} \mathrm{C}, 1.5 \mathrm{~h}\end{array}$ & 111 & 82.3 & - & $\begin{array}{l}\text { Reactive orange } \\
16(68.5)\end{array}$ & \\
\hline Fine powder & $\begin{array}{l}\text { Carbonization } \\
\mathrm{CO}_{2}, 850-950\end{array}$ & $\begin{array}{l}2,550^{\circ} \mathrm{C} \\
2-6 \mathrm{~h}\end{array}$ & 267 & 59.2 & - & - & $\begin{array}{l}\text { Fung et al. } \\
(2012)\end{array}$ \\
\hline \multirow[b]{2}{*}{$\begin{array}{l}\text { Granulated } \\
\text { form }\end{array}$} & $\begin{array}{l}\text { Demineralize } \\
\text { with alkali or }\end{array}$ & $\begin{array}{l}\text { Activation: } \mathrm{KOH}, 1: 1 \\
850^{\circ} \mathrm{C}, 60 \mathrm{~min}\end{array}$ & 242 & $20-78$ & $82.1(13.8)$ & - & \multirow[b]{2}{*}{$\begin{array}{l}\text { Lopez et al. } \\
\text { (2013) }\end{array}$} \\
\hline & $\begin{array}{l}\text { acid followed } \\
\text { by } \mathrm{HNO}_{3} / \mathrm{H}_{2} \mathrm{O} \\
\text { treatment }\end{array}$ & $\begin{array}{l}\mathrm{N}_{2}, 100 \mathrm{~mL} / \mathrm{min}, 800^{\circ} \mathrm{C} \\
\mathrm{CO}_{2}, 74 \mathrm{~mL} / \mathrm{min}, 800^{\circ} \mathrm{C}, \\
14 \mathrm{~h}, 850^{\circ} \mathrm{C}, 14 \mathrm{~h}\end{array}$ & 720 & 52 & (1) & th & \\
\hline \multirow{3}{*}{$\begin{array}{l}\text { Waste } \\
\text { bicycle tyre } \\
\text { (fine } \\
\text { powder) }\end{array}$} & \multicolumn{2}{|c|}{ Pyrolysis in open air } & - & - & - & $\begin{array}{l}\text { Methylene blue } \\
(10.24)\end{array}$ & \multirow{3}{*}{$\begin{array}{l}\text { Jha \& Subedi } \\
\text { (2011) }\end{array}$} \\
\hline & \multicolumn{2}{|c|}{ Pyrolysis in nitrogen, 60 bars } & - & - & - & $\begin{array}{l}\text { Methylene blue } \\
\text { (11.51) }\end{array}$ & \\
\hline & Pyrolysis in $\mathrm{n}$ & gen and steam & - & - & - & $\begin{array}{l}\text { Methylene blue } \\
(29.43)\end{array}$ & \\
\hline \multirow{2}{*}{$\begin{array}{l}\text { Waste } \\
\text { rubber tyre } \\
\text { tube }(1-3 \\
\mathrm{mm})\end{array}$} & \multirow{2}{*}{\multicolumn{2}{|c|}{$\begin{array}{l}\text { Partial carbonization: self-generated } \\
\text { atmosphere, } 200^{\circ} \mathrm{C}, 15 \mathrm{~min} \\
\text { Physical activation: self-generated } \\
\text { atmosphere, } 500-700^{\circ} \mathrm{C}, 60-120 \text { min } \\
\text { Impregnation: } \mathrm{ZnCl}_{2}, 1: 3\end{array}$}} & 7.52 & 41.6 & $12-20$ & 2,4-dichlorophenol & \multirow[t]{2}{*}{$\begin{array}{l}\text { Joseph et al. } \\
\text { (2015) }\end{array}$} \\
\hline & & & 15.4 & 44.9 & & 2,4-dichlorophenol & \\
\hline $\begin{array}{l}\text { Powder } \\
\text { from } \\
\text { cryogenic } \\
\text { and ambient } \\
\text { grinding }\end{array}$ & \multicolumn{2}{|c|}{$\begin{array}{l}\text { Impregnation: } \mathrm{H}_{3} \mathrm{PO}_{4}, 110^{\circ} \mathrm{C}, 2 \mathrm{~h} \\
\text { Carbonization: } \mathrm{N}_{2}, 650^{\circ} \mathrm{C}, 2.5 \mathrm{~h}\end{array}$} & 400 & - & $80-88$ & - & $\begin{array}{l}\text { Belgacem et al. } \\
\text { (2013) }\end{array}$ \\
\hline
\end{tabular}




\section{ACKNOWLEDGEMENT}

Financial support awarded by Universiti Teknologi Malaysia through RU-Grant No. 14H19 is gratefully acknowledged.

\section{REFERENCES}

Ahmad, F., Daud, W. M. A. W., Ahmad, M. A., Radzi, R. 2012. Cocoa (Theobroma cacao) shell-based activated carbon by $\mathrm{CO}_{2}$ activation in removing of Cationic dye from aqueous solution: Kinetics and equilibrium studies. Chem. Eng. Res. Des. 90(10), 1480-1490.

Belgacem, A., Belmedani, M., Rebiai, R., Hadoun, H. 2013. Characterization, analysis and comparison of activated carbons issued from the cryogenic and ambient grinding of used tyres. Chem. Eng. Trans. 32, 1705-1710.

Bensalah, N., Alfaro, M., Martínez-Huitle, C. 2009. Electrochemical treatment of synthetic wastewaters containing alphazurine A dye. Chem. Eng. J. 149(1), 348-352.

Chen, C.L., Zhang, B.S., Chen, F.O. 2011. A novel method for calculating starch crystallinity. J Food Sci. 32(9), 68-70.

Crini, G. 2006. Non-conventional low-cost adsorbents for dye removal: A review. Bioresour. Technol. 97, 1061-1085.

Dawood, S., Sen, T.K., Phan, C. 2014. Synthesis and characterization of novel activated carbon from waste biomass pine cone and its application in the removal of congo red dye from aqueous solution by adsorption. Water Air Soil Pollut. 225(1), 1-16.

Downard, J., Singh, A., Bullard, R., Jayarathne, T., Rathnayake, C.M., Simmons, D.L., Wels, B.R, Spak, S.N., Peters, T., Beardsley, D., Stainer, C.O., Stone, E.A. 2015. Uncontrolled combustion of shredded tires in a landfill - Part 1: Characterization of gaseous and particulate emissions. Atmos. Environ. 104, 195-204.

Fung, P.P.M., Cheung, W.H., McKay, G. 2012. Systematic analysis of carbon dioxide activation of waste tire by factorial design. Chin. J. Chem. Eng. 20(3), 497-504.

Guo, L., Li, G., Liu, J., Meng, Y., Tang, Y. 2013. Adsorptive decolorization of methylene blue by crosslinked porous starch. Carbohydr. Polym. 93, 374 379.

Hita, I., Arabiourrutia, M., Olazar, M., Bilbao, J., Arandes, J.M., Castano, P. 2016. Opportunities and barriers for producing high quality fuels from the pyrolysis of scrap tires. Renew. Sustain. Energy Rev. 56, 745-759.

Ismail, B., Hussain, S.T., Akram, S. 2013. Adsorption of methylene blue onto spinel magnesium aluminate nanoparticles: Adsorption isotherms, kinetic and thermodynamic studies. Chem. Eng. J. 219, 395-402.

Jha, V. K., Subedi, K. 2011. Preparation of activated carbons from waste tire. Nepal Chem. Soc. 27, 19-25.

Joseph, C.G., Krishniah, D., Taufiq-Yap, Y.H., Massuanna, M., William, J. 2015. Preparation and characterization of activated carbon from waste rubber tires: A comparison between physical and chemical activation. $A d v$. Mater. Res. 1107, 347-352.
Kundu, S., Gupta, A.K. 2006. Arsenic adsorption onto iron oxide-coated cement (IOCC): Regression analysis of equilibrium data with several isotherm models and their optimization. Chem. Eng. J. 122, 93-106.

Langmuir, I. 1918. The adsorption of gases on plane surfaces of glass, mica and platinum. J. Am. Chem. Soc. 40(9), 1361-1403.

Lee, C. K., Low, K. S., Gan, P. Y. 1999. Removal of some organic dyes by acid treat spent bleaching earth. Environ. Technol. 20, 99-104.

Lee, J. W., Choi, S. P., Thiruvenkatachari, R., Shim, W. G., Moon, H. 2006. Evaluation of the performance of adsorption and coagulation processes for the maximum removal of reactive dyes. Dyes Pigm. 69(3), 196-203.

López, F. A., Centeno, T. A., Rodríguez, O., Alguacil, F.J. 2013. Preparation and characterization of activated carbon from the char produced in the thermolysis of granulated scrap tyres. J. Air Waste Manage. Assoc. 63(5), 534-544.

Miclescu, A., Wiklund, L. 2010. Methylene blue, an old drug with new indications? Romanian J. Anaesthesia Inten. Care. 17(1), 35-41.

Rangabhashiyam, S., Anu, N., Selvaraju, N. 2013. Sequestration of dye from textile industry wastewater using agricultural waste products as adsorbents. J. Environ. Chem. Eng. 1, 629-641.

Reza, R. A., Ahmaruzzaman, M. 2015. Comparative study of waste derived adsorbents for sequestering methylene blue from aquatic environment. $J$. Environ. Chem. Eng. 3, 395-404.

Rowhani, A., Rainey, T. 2016. Scrap tyre management pathways and their use as a fuel - A review. Energies. 9(2), 1-26.

Singh, A., Spak, S. N., Stone, E. A., Downard, J., Bullard, R., Pooley, M., Kostle, P. A., Mainprize, M. W., Wichman, M. D., Peters, T. M., Beardsley, D. and Stainer, C.O. 2015. Uncontrolled combustion of shredded tires in a landfill - Part 2: Population exposure, public health response, and an air quality index for urban fires. Atmos. Environ. 104, 273-283.

Torretta, V., Rada, E. C., Ragazzi, M., Trulli, E., Istrate, I. A., Cioca, L. I. 2015. Treatment and disposal of tyres: Two EU approaches. A review. Waste Manage. 45, 152-160.

Turer, A. 2012. Recycling of scrap tires. In Achilias, D. (Ed.). Material Recycling - Trends and Perspectives. 195-212. Rijeka: InTech Open.

Wróbel, D, Boguta, A, Ion, R. M. 2001. Mixtures of synthetic organic dyes in a photoelectrochemical cell. J. Photochem. Photobiol. Chem. 138(1), 7-22.

Yagub M. T., Sen, T. K., Afroze, S., Ang, H. M. 2014. Dye and its removal from aqueous solution by adsorption: A review. Adv. Colloid Interface Sci. 209, 172-184.

Zaini, M. A. A., Chai-Li, L. W., Kamaruddin, M. J., Mohd-Setapar, S. H., Che-Yunus, M. A. 2014a. Irradiated water-activated waste tyre powder for decolourization of reactive orange 16. J. Tek. Sci. Eng. 68(1), 95-100.

Zaini, M. A. A., Chiew-Ngiik, T., Kamaruddin, M. J., Mohd-Setapar, S. H., Che-Yunus, M. A. 2014b. Zinc chloride-activated waste carbon powder for decolourization of methylene blue. J. Tek. Sci. Eng. 67(2), 37-44. 